\title{
The effect of institutional differences on the economic development of German-speaking countries
}

\author{
Mikhail Savelyev ${ }^{1, *}$, Valery Ivanov², and Yury Polyakov² \\ ${ }^{1}$ Association for methodological assurance of business activity and social development "Mitra", 241 \\ Pushkinskaya street, Izhevsk, 426008, Russia, savelievmihail@mail.ru \\ ${ }^{2}$ Udmurt State University, 1 Universitetskaya Street, 426034 Izhevsk, Russia
}

\begin{abstract}
The growth rates and sustainability of economic development of five German-speaking countries: Austria, German Democratic Republic (GDR), Luxembourg, Federal Republic of Germany (FRG) and Switzerland in the period 1947-1990 are investigated. The comparison is carried out for five economic cycles of the united Germany over this period. The indicators of the standard deviation of the growth rates of real GDP and national income are used as a sustainability performance. It is revealed that the GDR's institutional system showed in a sustained way high growth rates, and after the isolation of West Berlin - favorable risks and firmness of prices. This system may even be regarded as the best institutional model of economic development for the German nation. At the moment of accession into the blocs, the member countries of the military and political bloc obtained benefits of development; during the exacerbation of the military and political situation, Switzerland, which was far from the contact of the blocs, became the winner, and during the detente - border Austria. Countries with smaller economies demonstrated greater institutional mobility.
\end{abstract}

\section{Introduction}

Studies of the impact of economic development on cultural environments and institutional differences under the escalation of civilizational conflicts from mostly academic explorations are becoming again an important means of ideological struggle and the search for competitive benefits of national development. To the joy of researchers, there are several phenomena in the 20th century when one nation was not just divided between different states, but there were marked institutional differences between these states. This enables us to estimate not only the impact of institutions on economic development in economic systems of the same technological level, but, on the one hand, to remove the cultural factor from the analysis. On the other hand, it gives us opportunity to draw a conclusion concerning the most authentic institutional models to the target culture. The theoretical foundation for the correspondence of the system of economic institutions to the country's culture has already been given by us in previous studies. [1-2].

\footnotetext{
${ }^{*}$ Corresponding author: savelievmihail@mail.ru
} 
Examples of such studies include the paper by L. Baltserovich and A. Zhontsy [3], where growth paths of Australia and New Zealand are correlated based on the similarity of their culture. In the work of A. Helantera and S.-E. Ollus [4] under the comparative analysis of Finland and Russia, it is asserted that the differences in the economic and technological development of these countries are defined by the role of the state. In the authors ' opinion, during the period under review, the government institutions established in Finland always demonstrated their competence in solving the issue of the promotion of economic growth., Russian government institutions, on the contrary, are unstable and bare of credit in society, whereby they have proved to be untenable in solving this task.

\section{Materials and methods}

Economic development is generally estimated by economic growth indicators, and much less attention is devoted to the study of sustainability. Moreover, the quantitative assessment of the resilience of macroeconomic systems does not have widely accepted indicators in the academic community. Consequently, the standard deviation (hereinafter referred to as the SD) of the country's real GDP growth rate is offered as such an indicator. This indicator is drafted similarly to technical analysis, where the most significant indicator of investment risk is $\mathrm{SD}$ of asset returns. The risk evaluation period is determined by the economic cycle from the first year of the beginning (or acceleration) of economic growth to the last year of the recession (or slowdown). This technique enables us to correctly exclude from the analysis the impact of all factors of cyclical economic development on the risk indicator, assessing, indeed, the quality of investment decisions made and the quality of their implementation in different institutional conditions of a certain culture.

The object of this study is the core of one of the world's civilizations - the countries of German culture. It is a group of countries where German is the first language or the second language for the majority of gainfully employed population: Germany, Austria, Switzerland, and Luxembourg. The most representative period of this research is the time from the the end of the Second World War to the dissolution of the socialist bloc, when Germany, the main country of the German world, was in a state of formational fragmentation into FRG and GDR. Two institutional models arose and existed simultaneously: the market-based private-capitalist model and the directive-state model. It is also interesting to compare Austria and Switzerland. They are two neutral countries, one of which was part of united nazi Germany before the end of the war, and the second one, which has traditionally been neutral since the Napoleonic wars. The third pair consists of Germany and Luxembourg. These countries are members of the same military - political bloc with a close political and institutional system, but they are significantly different in the size of their economies. The comparison of mainly Catholic and mainly Protestant countries that are neutral and part of military-political blocs is also of relevance.

Regrettably, we have not noticed a comparative study of these cultural and institutional phenomena. Particularly limited attention is paid to studies of the GDR economy. The history of post-war economic recovery in the East of Germany is reflected in the works of D. V. Kulbakin, H. Heitzer, A. Yu. Vatlin, and A. N. Samorukova [5-8]. B. V.Yablokov analyzes the features of practical implementation in the period from 1963 to 1973 of the "new economic system" of GDR. It effectively designed a simulated market mechanism within a centralized planned economy [9]. P. H. Ludz in the study of the period from 1961 to 1976 concludes that the leadership of GDR was not able to adapt the East German economy to a new type of industrial society that could link the advantages in the social sphere with the efficiency of the market economy [10].

The research material was the dynamics of changes in the real GDP of Germany as a whole, as well as Austria, Switzerland and Luxembourg for the period from 1947 to 1990. 
Angus Maddison Historical Statistics [11-12], Total economy database [13] и World Bank [14] were sources of data. Information from the first two sources are the same for the countries mentioned. Concerning Germany, Austria, Switzerland, and Luxembourg, the data from the third source differs significantly from the first two, since these are not research results and the facts from a financial institution have been updated for conservative purposes of Germany. There are no data on the real GDP of the GDR in the sources [11-14]. Thus, the comparative dynamics of changes in nominal GDP and national income was applied as an indicator of economic growth. This method permitted us to study the GDR's economic system for inflationary processes being another indicator of the economy's stability. We believe that due to the significant superiority of the size of the German economy over the GDR, the data of the united Germany are relevant to the Federal Republic of Germany with a slight correction in the direction reversed by the growth rate of the location of the GDR from the united Germany.

In our research, the growth rate of national income may be assumed to be similar to the growth rate of real GDP. In contrast to real GDP, national income does not contain depreciation charges. However, it should be considered that we analyze long periods of time during which machinery and equipment are in most cases fully depreciated. The difference between changes in national income and real GDP can be in the case of changes in the share of buildings and structures in the composition of fixed assets, depreciation of which is longer than machinery and equipment. In the history of GDR, we have not identified any major infrastructure projects that could significantly change the structure of fixed assets.

The data integrity for the GDR's nominal GDP was verified by comparing information from existing international databases like Angus Maddison Historical Statistics [11] and The Global Priceand Income History Group [15]. German sources from the time of socialist centralised planning were used (G. Heske, [16]). For the specified sources, the compared data coincided, as well as the dynamics of their changes. The data source on the growth rate of the GDR's national income was another similar German database (O. Schwarzer, [17]).

As indicators of the German - speaking countries which are the object of comparative analysis was used the geometric average rate of change in real GDP for each economic cycle (an indicator of economic growth) and the standard deviation of the same rate within the same cycles (an indicator of economic risk or sustainability of development). The data were combined into a common dot chart for each economic cycle for the countries analyzed.

\section{Results and discussion}

Economic development trends were formed by dividing the study period into the economic cycles of 1947-1958, 1959-1967, 1968-1975, 1976-1982 and 1983-1990, corresponding to the evolution in GDP of the country chosen as the comparison base, i.e. Germany as a whole. This periodization was amended in terms of the duration of the first (1950-1958) and last (1983-1988) economic cycles resulting from insufficient initial data concerning GDR. 


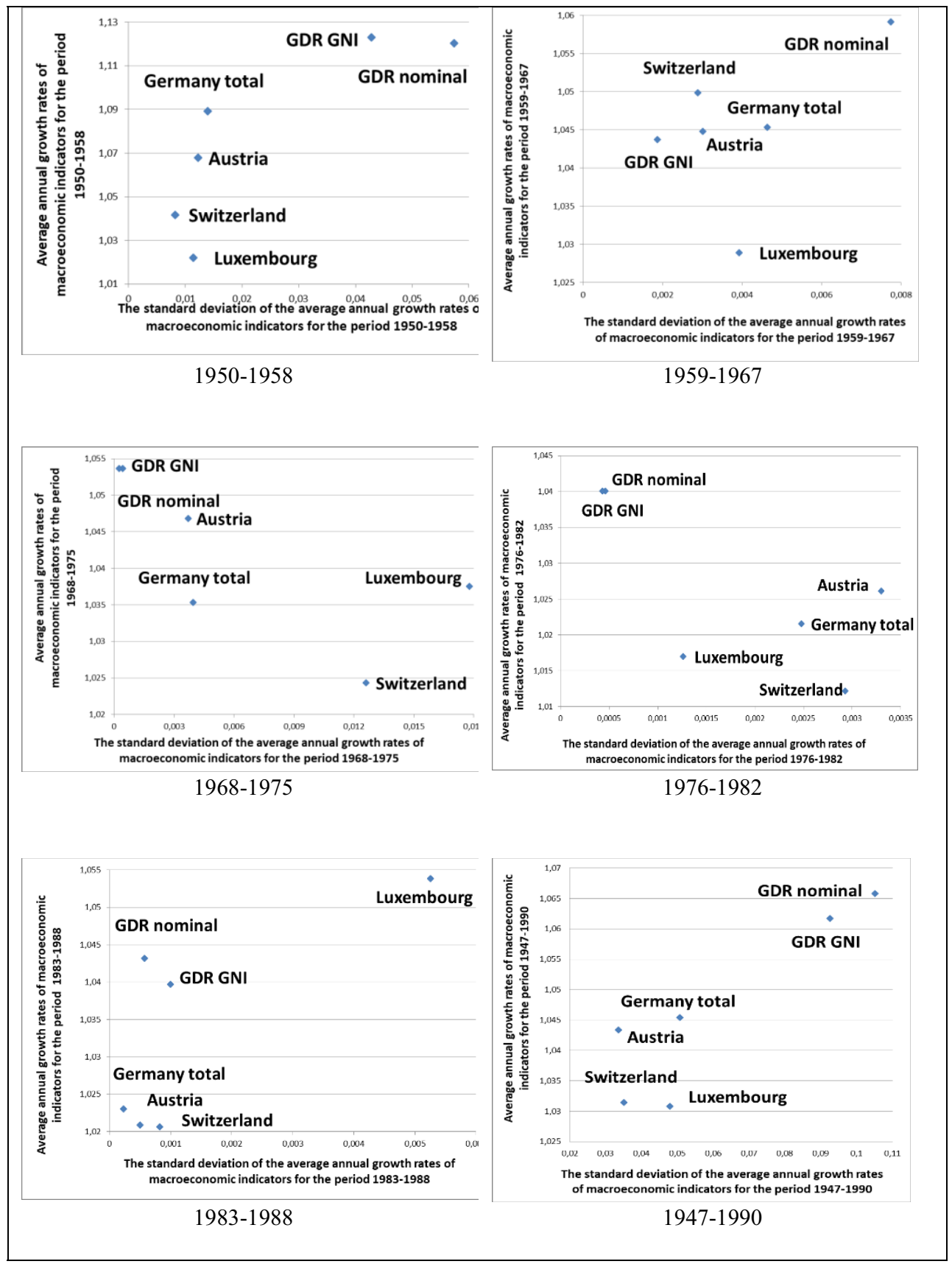

Fig.1.Economic development of the Germany countries

Analysis of the data obtained (Fig. 1) revealed that in three of the five periods, GDR economy had maximum growth and minimal risks. In addition to GDR, Switzerland demonstrated the highest growth in the second period, Luxembourg in the fifth, Switzerland had the lowest risk in the first period, and Germany in the last one. On the border of efficiency in the first period, you can observe Germany and Austria and in the fifth one - GDR. 
The inflationary processes in GDR indicate that deflation was seen in the first period, which, together with the highest economic growth in the history of German-speaking countries, may be regarded as an unattainable indicator for market-based private capitalist institutional models. In the second period, there was dotty ten percent prices leap in 1961 in connection with the famous political events on the dissolution of Berlin. Apparently, this crisis also affected the loss of GDR's leadership in economic growth. The next two periods of changes in nominal GDP and national income coincided, which signifies zero inflation and is unprecedented even for other socialist countries. It also confirmed our hypothesis that the growth of national income and GDP is comparable. In the last period, due to the roughly zero economic growth of the main outlet market (Comecon countries), there was some inflation in GDR. The second phenomenon of GDR is highly stable economic growth in non-inflationary periods, signified by an almost zero risk indicator.

Comparison of the neutral bloc countries indicates that during the flare-up of the military and political situation, the neutral ones like Switzerland that are more distant from the potential seat of war gain the upper hand. The border countries like Austria benefit during the detente period, and the bloc members are in the lead position during blocs formation. Smaller countries can modify their institutional policies more quickly due to their governance simplicity. This advantage was shown by Luxemburg in the fifth period under review. There were no visible differences between Protestant and Catholic countries.

\section{Conclusion}

Generally, it is safe to say that the institutional model implemented in GDR, according to maximum growth, its stability and firmness of prices, is the best in the history of the German nation. Moreover, among the private-capitalist market models, due to the studied characteristics, it is impossible to define the best or the worst one.

This conclusion enables us not only to rally to D. North's opinion concerning the importance of institutions, but also to contest his statement that only a private-capitalist institutional model may guarantee sustainable economic development. In this connection, an apparent refutation of his conclusions is drawn from the example of one of the fundamental cultures of Western civilization. This proof of the possibility of a polycentric world and the institutional variety of humanity negates the statement concerning the necessity of constructing the world economic system based on the institutional model of the global West.

Academic novelty elements are also the usage of measuring method of economic growth stability in order to estimate the quality of economic development and the detection of the phenomenon of cultural influence on the application of different institutional models.

\section{Acknowledgements}

The reported study was funded by RFBR, project number 20-010-00869

\section{References}

1. M.Yu. Savelyev, Multicultural institutionalism: General economic theory of civilizations. Political economy of traditionalism. Project of the network society, (Izhevsk: Association for methodological assurance of business activity and social development "Mitra”, 2015) (in Russian). http://cognitiofluctus.ru/science/s001/001.htm.

2. M.Yu. Savelyev, Bulletin of Udmurt University. Economics and Law series, 7, 66-75 (2015) (in Russian) URL: https://cyberleninka.ru/article/n/novye-formy-mezhtsivilizatsionnoy-konkurentsii-territoriy 
3. L. Baltserovich, A. Zhontsy, Mysteries of economic growth: forces and crises. A comparative analysis (Moscow: MYSL Publ. 2012) (in Russian)

4. A. Helantera, S.E. Ollus, Why Russia is not Finland? A comparative analysis of the competitiveness. (in Russian) URL:https://iq.hse.ru/news//177844707.html.

5. V.D. Kulbakin, History of German Democratic Republic (1949-1979) (Moscow: Nauka Publ., 1979) (in Russian)

6. Kh. Khayttser, 1949-1955. GDR: recovery and growth. (Moscow. 1977) (in Russian)

7. A.Yu. Vatlin, GDR: The construction of socialism in the time of Walter Ulbricht (1945-1971). Germany in the XX century (Moscow: Rossiyskaya politicheskaya entsiklopediya (ROSSREN) Publ., 2002) (in Russian)

8. A.N. Samorukova, Industrialization. Central and Eastern Europe in the second half of the XX century, The establishment of "real socialism" (1945-1965) (Moscow, 2000) (in Russian).

9. B.V. Yablokov, Foreign economic policy of GDR in the "New economic system" (19631973). Dissertation on competition of a scientific degree of Candidate $(\mathrm{PhD})$ of historical Sciences (Moscow, 2018) (in Russian) URL: http://igh.ru/system/dissertations/dissertation_pdfs/000/000/017/original/b13e36dfa2bb3dc2ddfd394ce7734723d7febf39.pdf?1518015081

10. P.C. Ludz, Die DDR zwischen Ost und West, Politische Analyse (1961-1976) (München, 1977)

11. Angus Maddison Historical Statistics. http://www.ggdc.net/MADDISON/oriindex.html

12. J. Bolt, J.L. van Zanden, Economic History Review, 67(3), 627-651 (2014)

13. Total economy database (TED), https://www.conference-board.org/data/economydatabase

14. World Bank, "World Development Indicators". https://databank.worldbank.org/source/world-development-indicators

15. The Global Price and Income History Group (GPIH)

16. G. Heske, Historical Social Research, Supplement, 21, 1-359 (2009) https://nbn-resolving.org/urn:nbn:de:0168-ssoar-285875

17. Oskar Schwarzer, Sozialistische Zentralplanwirtschaft in der SBZ/DDR, 1945 - 1989. GESIS Datenarchiv, Köln. ZA8391 Datenfile Version 1.0.0, (2010) https://doi.org/10.4232/1.10258 